\title{
Front Matter: Volume 7901
}

, "Front Matter: Volume 7901," Proc. SPIE 7901, Energy-based Treatment of Tissue and Assessment VI, 790101 (30 March 2011); doi: 10.1117/12.890770

SPIE. Event: SPIE BiOS, 2011, San Francisco, California, United States 


\section{PROGRESS IN BIOMEDICAL OPTICS AND IMAGING}

Vol. 12, No. 19

\section{Energy-based Treatment of Tissue and Assessment VI}

Thomas P. Ryan

Editor

23-24 January 2011

San Francisco, California, United States

Sponsored and Published by

SPIE

Volume 7901

Proceedings of SPIE, 1605-7422, v. 7901

SPIE is an international society advancing an interdisciplinary approach to the science and application of light. 
The papers included in this volume were part of the technical conference cited on the cover and title page. Papers were selected and subject to review by the editors and conference program committee. Some conference presentations may not be available for publication. The papers published in these proceedings reflect the work and thoughts of the authors and are published herein as submitted. The publisher is not responsible for the validity of the information or for any outcomes resulting from reliance thereon.

Please use the following format to cite material from this book:

Author(s), "Title of Paper," in Energy-based Treatment of Tissue and Assessment VI, edited by Thomas P. Ryan, Proceedings of SPIE Vol. 7901 (SPIE, Bellingham, WA, 2011) Article CID Number.

ISSN $1605-7422$

ISBN 9780819484383

Published by

SPIE

P.O. Box 10, Bellingham, Washington 98227-0010 USA

Telephone +1 3606763290 (Pacific Time) · Fax +1 3606471445

SPIE.org

Copyright @ 2011 , Society of Photo-Optical Instrumentation Engineers.

Copying of material in this book for internal or personal use, or for the internal or personal use of specific clients, beyond the fair use provisions granted by the U.S. Copyright Law is authorized by SPIE subject to payment of copying fees. The Transactional Reporting Service base fee for this volume is $\$ 18.00$ per article (or portion thereof), which should be paid directly to the Copyright Clearance Center (CCC), 222 Rosewood Drive, Danvers, MA 01923. Payment may also be made electronically through CCC Online at copyright.com. Other copying for republication, resale, advertising or promotion, or any form of systematic or multiple reproduction of any material in this book is prohibited except with permission in writing from the publisher. The CCC fee code is 1605$7422 / 11 / \$ 18.00$.

Printed in the United States of America.

Publication of record for individual papers is online in the SPIE Digital Library.

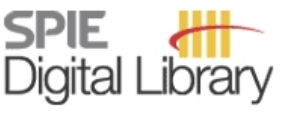

SPIEDigitalLibrary.org

Paper Numbering: Proceedings of SPIE follow an e-First publication model, with papers published first online and then in print and on CD-ROM. Papers are published as they are submitted and meet publication criteria. A unique, consistent, permanent citation identifier (CID) number is assigned to each article at the time of the first publication. Utilization of CIDs allows articles to be fully citable as soon they are published online, and connects the same identifier to all online, print, and electronic versions of the publication. SPIE uses a six-digit CID article numbering system in which:

- The first four digits correspond to the SPIE volume number.

- The last two digits indicate publication order within the volume using a Base 36 numbering system employing both numerals and letters. These two-number sets start with 00, 01, 02, 03, 04 , 05, 06, 07, 08, 09, 0A, OB ... 0Z, followed by 10-1Z, 20-2Z, etc.

The CID number appears on each page of the manuscript. The complete citation is used on the first page, and an abbreviated version on subsequent pages. Numbers in the index correspond to the last two digits of the six-digit CID number. 


\section{Contents}

ix Conference Committee

xi Introduction

\section{KEYNOTE SESSION}

790102 The art and science of low-energy applications in medicine: pathology perspectives (Keynote Paper) [7901-01]

S. Thomsen, Pathology Consultant (United States)

790103 Practical pathology perspectives for minimally invasive hyperthermic medical devices (Keynote Paper) [7901-46]

J. E. Coad, West Virginia Univ. (United States)

\section{LOW ENERGY NON-ABLATIVE TISSUE EFFECTS}

790104 Non-ablative hyperthermic mesenchymal regeneration: a proposed mechanism of action based on the Viveve model (Invited Paper) [7901-03]

J. A. Vos, R. H. Livengood, M. Jessop, J. E. Coad, West Virginia Univ. (United States)

790105 The influence of electric charge transferred during electro-mechanical reshaping on mechanical behavior of cartilage [7901-04]

D. E. Protsenko, A. Lim, E. C. Wu, C. Manuel, Beckman Laser Institute (United States);

B. J. F. Wong, Beckman Laser Institute (United States) and Univ. of California, Irvine (United States)

THERMAL TREATMENT: PLANNING, NAVIGATION, AND ASSESSMENT

790106 Strategies for microwave thermal treatment planning, navigation, and assessment (Invited Paper) [7901-05]

T. P. Ryan, FreeFall Consulting (United States)

790107 Conformal needle-based ultrasound ablation using EM-tracked conebeam CT image guidance (Invited Paper) [7901-06]

E. C. Burdette, Acoustic Medsystems, Inc. (United States); F. Banovac, Georgetown Univ. Medical Ctr. (United States); C. J. Diederich, Univ. of California, San Francisco (United States); P. Cheng, E. Wilson, K. R. Cleary, Georgetown Univ. Medical Ctr. (United States)

790108 Preliminary evaluation of robotic needle distal tip repositioning (Invited Paper) [7901-07] C. J. Walsh, Massachusetts General Hospital (United States) and Massachusetts Institute of Technology (United States); A. H. Slocum, Massachusetts Institute of Technology (United States); R. Gupta, Massachusetts General Hospital (United States) 
790109 Thermal treatment planning for SonoKnife focused-ultrasound thermal treatment of head and neck cancers [7901-08]

X. Chen, D. Chen, R. Xia, G. Shafirstein, P. Corry, E. G. Moros, Univ. of Arkansas for Medical Sciences (United States)

\section{NANOPARTICLES AND NANOTHERAPY I}

7901 OA Nanoparticle-based cancer treatment: can delivered dose and biological dose be reliably modeled and quantified? (Invited Paper) [7901-09]

P. J. Hoopes, Dartmouth Medical School (United States) and Dartmouth College (United States); A. A. Petryk, Dartmouth College (United States); A. J. Giustini, Dartmouth Medical School (United States) and Dartmouth College (United States); R. V. Stigliano, R. N. D'Angelo, J. A. Tate, S. M. Cassim, A. Foreman, Dartmouth College (United States); J. C. Bischof, Univ. of Minnesota, Twin Cities (United States); J. C. Pearce, The Univ. of Texas at Austin (United States); T. Ryan, Freefall Consulting (United States)

7901 OB FEM numerical model study of heating in magnetic nanoparticles (Invited Paper) [7901-10] J. A. Pearce, J. R. Cook, The Univ. of Texas at Austin (United States); P. J. Hoopes, A. Giustini, Dartmouth Medical School (United States) and Dartmouth College (United States)

7901 OC Nanoparticle heating: nanoscale to bulk effects of electromagnetically heated iron oxide and gold for biomedical applications [7901-11]

Z. Qin, M. Etheridge, J. C. Bischof, Univ. of Minnesota, Twin Cities (United States)

7901 OD Modelling and characterization of photothermal effects assisted with gold nanorods in ex vivo samples and in a murine model [7901-12]

H. Lamela Rivera, F. Rodríguez Jara, V. Cunningham, Univ. Carlos III de Madrid (Spain)

$7901 \mathrm{OE} \quad$ Comparison of microwave and magnetic nanoparticle hyperthermia radiosensitization in murine breast tumors [7901-13]

A. J. Giustini, Dartmouth Medical School (United States) and Dartmouth College (United States); A. A. Petryk, Dartmouth College (United States); P. J. Hoopes, Dartmouth Medical School (United States) and Dartmouth College (United States)

\section{MICRO-TISSUE EFFECTS}

7901 OF Computational modeling of high-intensity focused ultrasound mediated drug delivery (Invited Paper) [7901-14]

A. Gasselhuber, Medical Univ. of South Carolina (United States) and Vienna Univ. of Technology (Austria); S. Appanaboyina, Medical Univ. of South Carolina (United States); M. Dreher, A. Partanen, B. Wood, National Cancer Institute (United States); F. Rattay, Vienna Univ. of Technology (Austria); D. Haemmerich, Medical Univ. of South Carolina (United States) and Clemson Univ. (United States)

$79010 G$ Determination of cellular injury and death thresholds following exposure to high voltage 10ns electrical pulses [7901-15]

B. L. Ibey, Air Force Research Lab. (United States); C. C. Roth, General Dynamics Information Technology (United States); J. A. Bernhard, Air Force Research Lab. (United States);

A. G. Pakhomov, Old Dominion Univ. (United States); G. J. Wilmink, Air Force Research Lab. (United States); O. Pakhomova, Old Dominion Univ. (United States) 
$7901 \mathrm{OH} \quad$ How does temperature affect the function of tissue macrophages? [7901-16]

C.-T. Lee, E. A. Repasky, Roswell Park Cancer Institute (United States)

7901 0J Lysosomal exocytosis in response to subtle membrane damage following nanosecond pulse exposure [7901-18]

D. R. Dalzell, Air Force Research Lab. (United States); C. C. Roth, General Dynamics Information Technology (United States); J. A. Bernhard, J. A. Payne, G. J. Wilmink, B. L. Ibey, Air Force Research Lab. (United States)

7901 OK Effects of femtosecond laser radiation on blood cell suspensions [7901-19] T. Gening, Ulyanovsk State Univ. (Russian Federation); A. Sysolyatin, Fiber Optics Research Ctr. (Russian Federation); T. Abakumova, D. Arslanova, O. Voronova, I. Zolotovsky,

V. Ostatochnikov, M. Yavtushenko, Ulyanovsk State Univ. (Russian Federation)

7901 OL Removal of brain tissue by 1940-nm Tm-Fiber laser [7901-20]

B. Tunç, M. Gülsoy, Bogaziçi Üniv. Institute of Biomedical Engineering (Turkey)

ULTRASOUND: SIMULATIONS, IMAGING, AND TREATMENT

7901 OM Magnetic resonance-guided focused ultrasound surgery for treatment of painful osseous metastases (Invited Paper) [7901-21]

M. Hurwitz, Dana-Farber/Brigham and Women's Cancer Ctr., Harvard Medical School (United States); R. Machtinger, F. Fennessy, Brigham and Women's Hospital, Harvard Medical School (United States)

7901 ON Microwave thermal imaging of scanned focused ultrasound heating: animal experiments [7901-22]

T. Zhou, P. M. Meaney, Dartmouth College (United States); J. P. Hoopes, Dartmouth Medical School (United States); S. D. Geimer, K. D. Paulsen, Thayer School of Engineering (United States)

790100 Catheter-based ultrasound hyperthermia with HDR brachytherapy for treatment of locally advanced cancer of the prostate and cervix (Invited Paper) [7901-23]

C. J. Diederich, J. Wootton, Univ. of California, San Francisco (United States) and Univ. of California, Berkeley (United States); P. Prakash, V. Salgaonkar, T. Juang, Univ. of California, San Francisco (United States); S. Scott, Univ. of California, San Francisco (United States) and Univ. of California, Berkeley (United States); X. Chen, A. Cunha, J. Pouliot, I. C. Hsu, Univ. of California, San Francisco (United States)

7901 OP Fast optimization and planning of clinical interstitial ultrasound hyperthermia using superposition and surrogate models of temperature distributions [7901-38] V. A. Salgaonkar, P. Prakash, C. J. Diederich, Univ. of California, San Francisco (United States)

$79010 Q$ Experimental characterization of a SonoKnife applicator [7901-25] R. Xia, D. Chen, G. Shafirstein, X. Chen, P. Corry, R. Griffin, E. G. Moros, Univ. of Arkansas for Medical Sciences (United States) 
7901 OR Hepatic ablation with multiple interstitial ultrasound applicators: initial ex vivo and computational studies [7901-26]

P. Prakash, V. A. Salgaonkar, Univ. of California, San Francisco (United States); E. C. Burdette, Acoustic Medsystems, Inc. (United States); C. J. Diederich, Univ. of California, San Francisco (United States)

\section{SENSORS AND RADIOMETRY}

7901 OS Investigation of the electrical conductivity in perfused liver using micro electrical probe [7901-27]

M. Yi, Virginia Polytechnic Institute and State Univ. (United States) and IBM China Co. Ltd. (China); R. J. Podhajsky, Covidien (United States); R. L. Mahajan, Virginia Polytechnic Institute and State Univ. (United States)

7901 OT Ultra-miniature wireless temperature sensor for thermal medicine applications [7901-28] A. Khairi, S.-C. Hung, J. Paramesh, G. Fedder, Y. Rabin, Carnegie Mellon Univ. (United States)

7901 OU Electrical property-based biopsy for prostate cancer detection and assessment [7901-29] R. J. Halter, Dartmouth College (United States), Dartmouth Medical School (United States), and Norris Cotton Cancer Ctr. (United States); V. Mishra, H. Bouayad, P. Manwaring, Dartmouth College (United States); J. Heaney, Dartmouth College (United States), Dartmouth Medical School (United States), Darmouth-Hitchcock Medical Ctr. (United States), and Norris Cotton Cancer Ctr. (United States); A. Schned, Dartmouth Medical College (United States), Darmouth-Hitchcock Medical Ctr. (United States), and Norris Cotton Cancer Ctr. (United States)

7901 OV Microwave radiometry for non-invasive detection of vesicoureteral reflux (VUR) following bladder warming (Invited Paper) [7901-30]

P. R. Stauffer, P. F. Maccarini, Duke Univ. (United States); K. Arunachalam, Indian Institute of Technology (India); V. De Luca, S. Salahi, A. Boico, Duke Univ. (United States); O. Klemetsen, Y. Birkelund, S. K. Jacobsen, Univ. of Tromso (Norway); F. Bardati, Univ. of Roma Tor Vergata (Italy); P. Tognolotti, Univ. dell'Aguila (Italy); B. Snow, The Univ. of Utah (United States)

\section{TISSUE TREATMENT EFFECTS I}

7901 OW Ultrasound therapy applicators for controlled thermal modification of tissue (Invited Paper) [7901-31]

E. C. Burdette, Acoustic Medsystems, Inc. (United States); C. Lichtenstiger, L. Rund, Univ. of Illinois (United States); M. Keralapura, Univ. of California, San Francisco (United States);

C. Gossett, R. Stahlhut, P. Neubauer, B. Komadina, E. Williams, C. Alix, Acoustic Medsystems, Inc. (United States); T. Jensen, L. Schook, Univ. of Illinois (United States); C. J. Diederich, Univ. of California, San Francisco (United States)

7901 0X 1125-nm quantum dot laser for tonsil thermal therapy (Invited Paper) [7901-32] K. McMillan, gRadiant Research, LLC (United States)

7901 OY Hyperthermic tissue sealing devices: a proposed histopathologic protocol for standardizing the evaluation of thermally sealed vessels (Invited Paper) [7901-33]

R. H. Livengood, J. A. Vos, J. E. Coad, West Virginia Univ. (United States) 
$79010 Z$ Dual thermal ablation modality of solid tumors in a mouse model (Invited Paper) [7901-34] G. Shafirstein, K. Barnes, L. Hennings, J. Webber, E. G. Moros, B. Przybyla, R. J. Griffin, Univ. of Arkansas for Medical Sciences (United States)

790110 Arrhenius parameters for primary thermal injury in human tonsillar tissue [7901-35] K. McMillan, gRadiant Research, LLC (United States); R. Radabaugh, J. E. Coad, West Virginia Univ. (United States)

\section{TISSUE TREATMENT EFFECTS II}

$790111 \quad$ New visualization strategy to study the dynamics of surgical coagulation devices in biological tissue using absolute subsurface thermal imaging [7901-36]

S. L. Been, Univ. Medical Ctr. Utrecht (Netherlands); R. M. Verdaasdonk, Vrije Univ. Medical Ctr. (Netherlands); J. H. G. M. Klaessens, Univ. Medical Ctr. Utrecht (Netherlands)

790112 Indocyanine green enhanced near infrared laser treatment of SCK tumors in a mouse model pilot study [7901-37]

G. Shafirstein, Univ. of Arkansas for Medical Sciences (United States); W. Bäumler, Univ. Clinics Regensburg (Germany); R. Friedman, L. Hennings, J. Webber, J. Suen,

R. J. Griffin, Univ. of Arkansas for Medical Sciences (United States)

790113 Computed effects of sweat gland ducts on the propagation of $94 \mathbf{~ G H z}$ waves in skin [7901-45]

G. Shafirstein, E. G. Moros, Univ. of Arkansas for Medical Sciences (United States)

\section{NANOPARTICLES AND NANOTHERAPY II}

790115 Development of novel magnetic nanoparticles for hyperthermia cancer therapy [7901-40] S. M. Cassim, Dartmouth College (United States); A. J. Giustini, Dartmouth College (United States) and Dartmouth Medical School (United States); I. Baker, Dartmouth College (United States); P. J. Hoopes, Dartmouth College (United States) and Dartmouth Medical School (United States)

790116 Selective nanoparticle-directed photothermal ablation of the canine prostate [7901-41] J. A. Schwartz, Nanospectra Biosciences, Inc. (United States); R. E. Price, Baylor College of Medicine (United States); K. L. Gill-Sharp, K. L. Sang, J. D. Khorchani, J. D. Payne, Nanospectra Biosciences, Inc. (United States); B. S. Goodwin, The Univ. of Texas Health Science Ctr. at Houston (United States)

790117 In vivo biodistribution of iron oxide nanoparticles: an overview [7901-42] J. A. Tate, A. A. Petryk, Thayer School of Engineering, Dartmouth College (United States); A. J. Giustini, Thayer School of Engineering, Dartmouth College (United States) and Dartmouth Medical School (United States); P. J. Hoopes, Dartmouth Medical School (United States)

790118 Kinetics and pathogenesis of intracellular magnetic nanoparticle cytotoxicity [7901-43] A. J. Giustini, Dartmouth Medical School (United States) and Dartmouth College (United States); R. E. Gottesman, A. A. Petryk, A. M. Rauwerdink, Dartmouth College (United States); P. J. Hoopes, Dartmouth Medical School (United States) and Dartmouth College (United States) 
790119 Comparison of iron oxide nanoparticle and microwave hyperthermia alone or combined with cisplatinum in murine breast tumors [7901-44]

A. A. Petryk, R. V. Stigliano, Thayer School of Engineering, Dartmouth College (United States); A. J. Giustini, Thayer School of Engineering, Dartmouth College (United States) and Dartmouth Medical School (United States); R. E. Gottesman, Carleton College (United States); B. S. Trembly, Thayer School of Engineering, Dartmouth College (United States); P. A. Kaufman, Dartmouth-Hitchcock Medical Center (United States); P. J. Hoopes, Thayer School of Engineering, Dartmouth College (United States) and Dartmouth Medical School (United States))

Author Index 


\title{
Conference Committee
}

\author{
Symposium Chairs \\ James G. Fujimoto, Massachusetts Institute of Technology (United \\ States) \\ R. Rox Anderson, Wellman Center for Photomedicine, Massachusetts \\ General Hospital, Harvard School of Medicine (United States)
}

Program Track Chairs

Steven L. Jacques, Oregon Health \& Science University (United States)

William P. Roach, U.S. Air Force (United States)

Conference Chair

Thomas P. Ryan, Freefall Consulting (United States)

Program Committee

James E. Coad, West Virginia University (United States)

Chris J. Diederich, University of California, San Francisco (United States)

P. Jack Hoopes, Dartmouth Hitchcock Medical Center (United States)

John A. Pearce, University of Texas at Austin (United States)

Paul R. Stauffer, Duke University (United States)

Sharon L. Thomsen, Consultant (United States)

\section{Session Chairs}

1 Low Energy Non-Ablative Tissue Effects

Thomas P. Ryan, Freefall Consulting (United States)

2 Thermal Treatment: Planning, Navigation, and Assessment

Paul R. Stauffer, Duke University (United States)

3 Nanoparticles and Nanotherapy I

Yoed Rabin, Carnegie Mellon University (United States)

Panel Discussion: Nanoparticle and Nanotherapy Controversies

Chris Diederich, University of California, San Francisco (United States)

$4 \quad$ Micro-tissue Effects

James E. Coad, West Virginia University (United States) 
Questions and Answers

James E. Coad, West Virginia University (United States)

$5 \quad$ Ultrasound: Simulations, Imaging, and Treatment

Everette C. Burdette, Acoustic Medsystems, Inc. (United States)

6 Sensors and Radiometry

John A. Pearce, The University of Texas at Austin (United States)

7 Tissue Treatment Effects I

P. Jack Hoopes, Dartmouth Medical School (United States)

8 Tissue Treatment Effects II

Sharon L. Thomsen, Consultant (United States)

9 Nanoparticles and Nanotherapy II

Gal Shafirstein, University of Arkansas for Medical Sciences (United States) 


\section{Introduction}

Welcome to the 2011 proceedings for the SPIE conference Energy-based Treatment of Tissue and Assessment VI. We have been organizing this conference since 1998 and this year has proven to be the best conference yet.

The variety and diversity of papers for the 2011 conference was even greater than in the past. We started with low-energy, non-ablative tissue effects and worked our way through treatment planning, navigation, and assessment into tissue effects and thermal ablation. We also included updates on therapeutic ultrasound sensors and radiometry. There were two complete sessions on nanoparticles, encompassing the biochemistry of nanoparticle construction, delivery, tissue effects, success in tumor treatment, and imaging. This year we also had a panel discussion on nanoparticles with a strong group of experts to review the challenges.

Our goal for this conference has always been to attract a diversity of participants, including physicists, engineers, scientists, and physicians from a variety of disciplines including pathology, since our goal has always been specific tissue effects, especially that of cancer treatment. The diversity is seen clearly in our participants, but also extends to the presentations and the papers. The international gathering at the conference was very fruitful for networking, scientific exchanges, and collaboration. Many participants walked away with potential collaborators whom they newly met at the meeting. So enjoy these proceedings and its relevance to the topics of thermal therapy and tissue assessment.

Thomas P. Ryan 
Downloaded From: https://www.spiedigitallibrary.org/conference-proceedings-of-spie on 26 Apr 2023

Terms of Use: https://www.spiedigitallibrary.org/terms-of-use 